\title{
Luminescence Dates from the Tuinier Farm Site (41HP237), Hopkins County, Texas
}

Timothy K. Perttula

Heritage Research Center, Stephen F. Austin State University

James K. Feathers

Follow this and additional works at: https://scholarworks.sfasu.edu/ita

Part of the American Material Culture Commons, Archaeological Anthropology Commons, Environmental Studies Commons, Other American Studies Commons, Other Arts and Humanities Commons, Other History of Art, Architecture, and Archaeology Commons, and the United States History Commons

Tell us how this article helped you.

This Article is brought to you for free and open access by the Center for Regional Heritage Research at SFA ScholarWorks. It has been accepted for inclusion in Index of Texas Archaeology: Open Access Gray Literature from the Lone Star State by an authorized editor of SFA ScholarWorks. For more information, please contact cdsscholarworks@sfasu.edu. 


\section{Luminescence Dates from the Tuinier Farm Site (41HP237), Hopkins County,}

Texas

\section{Creative Commons License}

(c) (1) (2)

This work is licensed under a Creative Commons Attribution-NonCommercial 4.0 International License 


\title{
LUMINESCENCE DATES FROM THE TUINIER FARM SITE (41HP237), HOPKINS COUNTY, TEXAS
}

\author{
Timothy K. Perttula and James K. Feathers
}

\author{
Introduction
}

The luminescence dating of ceramics (see Feathers 1997, 2000, 2003) has been applied with some considerable success in a variety of settings-and on different ceramic wares-in North America (Lipo et al. 2005; Dykeman et al. 2002; Feathers 2009), but since the days of Alpha Analytic (a subsidiary of Beta Analytic) in the early to mid-1980s, there have been no luminescence dating of Caddo ceramic wares in Northeast or East Texas. Given the abundance of ceramics of several different kinds and styles at all Caddo sites, the luminescence dating of both plain and decorated sherds recovered in situ from these many sites should be explored since it is a method "that dates the manufacture and use of...ceramic objects [that] provide a closer relationship between the target event [when a site is occupied] and the dated event [the age determined by the luminescence on a sherd]. Luminescence is particularly well suited for the dating of ceramics since the method measures the time elapsed since vessels were last heated, usually corresponding to manufacture or use" (Lipo et al. 2005:535). In this article, we discuss the results of recent luminescence dating on a small sample of Caddo ceramic sherds at the Tuinier Farm site (41HP237).

\section{Tuinier Farm Site (41HP237)}

The Tuinier Farm site is thought to be a $16^{\text {th }}$ to $17^{\text {th }}$ century Caddo site in the modern-day Post Oak Savanna of Northeast Texas (Diggs et al. 2006:Figure 2). It is a Late Caddo period Titus phase habitation site with midden deposits, features, and an associated cemetery (Perttula 2009). In this region, based on more than 100 calibrated radiocarbon dates from a variety of sites and contexts within them, Titus phase sites date within the ca. 250 year interval of ca. A.D. 1430-1680.

Two radiocarbon dates have been obtained from the Tuinier Farm site (Table 1). The samples submitted for radiocarbon analysis are charred Hickory (Carya sp.) nutshells from flotation samples in the South midden.

Table 1. Radiocarbon dates from the Tuinier Farm site.

\begin{tabular}{|c|c|c|c|c|c|}
\hline Beta No. & Provenience & $\begin{array}{l}\text { Conventional } \\
\text { radiocarbon age } \\
\text { (B.P.) }\end{array}$ & $\begin{array}{l}\text { Calibrated } \\
\text { intercept* }\end{array}$ & $\begin{array}{l}\text { Calibrated } \\
1 \text { sigma } \\
\text { age range }\end{array}$ & $\begin{array}{l}\text { Calibrated } \\
2 \text { sigma } \\
\text { age range }\end{array}$ \\
\hline B-239189 & $\begin{array}{l}\text { Unit } 4,10-20 \\
\mathrm{~cm} \mathrm{bs}\end{array}$ & $260 \pm 40$ & AD 1650 & AD 1640-1660 & $\begin{array}{l}\text { AD } 1520-1590 \\
\text { AD } 1620-1670 \\
\text { AD } 1770-1800^{* *} \\
\text { AD } 1940-1950 *\end{array}$ \\
\hline Beta No. & Provenience & $\begin{array}{l}\text { Conventional } \\
\text { radiocarbon age } \\
\text { (B.P.) }\end{array}$ & $\begin{array}{l}\text { Calibrated } \\
\text { intercept* }\end{array}$ & $\begin{array}{l}\text { Calibrated } \\
1 \text { sigma } \\
\text { age range }\end{array}$ & $\begin{array}{l}\text { Calibrated } \\
2 \text { sigma } \\
\text { age range }\end{array}$ \\
\hline B-239188 & $\begin{array}{l}\text { Unit } 4,20-30 \\
\mathrm{~cm} \mathrm{bs}\end{array}$ & $400 \pm 40$ & $\mathrm{AD} 1460$ & AD 1440-1490 & $\begin{array}{l}\text { AD } 1430-1530 \\
\text { AD } 1560-1630\end{array}$ \\
\hline
\end{tabular}

*calibrated following Reimer et al. (2004) and IntCal04; **unrealistically young. 
The calibrated intercepts suggest that the Caddo occupation at the Tuinier Farm (or at least that part of the South midden occupation in the vicinity of the Unit 4 archeological deposits) may have begun as

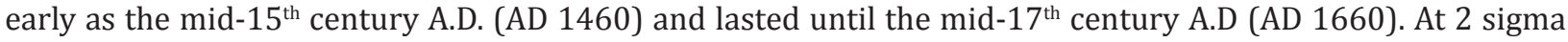
(95\% probability), the two calibrated radiocarbon dates overlap between AD 1520-1630 (Table 1), and this is considered the most likely chronological range of the domestic Caddo occupation at Tuinier Farm; the burials at this site may be younger than that based on the presence of a mid- $17^{\text {th }}$ century style Taylor Engraved inverted rim carinated bowl.

About $91 \%$ of the engraved fine ware sherds from the site are from Ripley Engraved vessels (Perttula 2009:Table 5), mostly carinated bowls, based on the kinds of engraved motifs found on the rim panel of vessels. There is also a smattering of Taylor Engraved and probable Hodges and Womack Engraved types in the Tuinier Farm fine ware sherds. There is also one shell-tempered Avery Engraved vessel sherd from a trade vessels that likely was manufactured on a post-A.D. 1400 Caddo site along the Red River, well to the north of the Stouts Creek area. Taken together, the co-association of these engraved fine ware types suggests that the Caddo occupation at the Tuinier Farm site postdates ca. A.D. 1550, and certainly lasted into the $17^{\text {th }}$ century A.D. The occupation could have lasted as late as the mid- to late $17^{\text {th }}$ century given the known chronological age range of Titus phase sites (see Perttula 2005:364-370).

\section{Luminescence Analyses}

Table 2 lists the samples submitted from the Tuinier Farm site, their vertical provenience, and their expected age based on the identification of Titus phase ceramic styles in the large sherd assemblage and associated radiocarbon dates (see Perttula 2009:12-23 and Table 1). All the sherds are from Unit 4 in the South midden.

Table 2. Sherds submitted from the Tuinier Farm (41HP237) for Luminescence dating.

\begin{tabular}{c|ccccc}
\hline Sample \# & UW lab\# & site & Depth $(\mathrm{cm} \mathrm{bs})$ & Ceramic type & Expected age (years AD) \\
\hline TL-1 & UW1943 & $41 \mathrm{HP} 237$ & 19 & Plain body & Post-1500 \\
TL-2 & UW1944 & $41 \mathrm{HP} 237$ & 19 & Engraved carinated bowl & Post-1500 \\
& & & & & \\
TL-3 & UW1945 & $41 \mathrm{HP} 237$ & 14 & McKinney Plain body & Post-1500 \\
TL-4 & UW1946 & $41 \mathrm{HP} 237$ & 16 & Anglin Impressed & Post-1500 \\
\hline
\end{tabular}

Dose rate measurements were made on each sample as well as an associated sediment sample. The difference in radioactivity between sherds and associated sediments was not great, suggesting the ceramics were made from similar material as the sediments. Dose rates were determined using alpha counting and flame photometry. The beta dose rate calculated from these measurements was compared with the beta dose rate measured directly by beta counting. These were in agreement for the Tuinier Farm samples. Moisture content was estimated as $80 \pm 20 \%$ of saturated value for the sherds, and $10 \pm 5$ percent for the sediments. Table 3 gives all relevant data, including the total dose rate for each sample. Total dose rate is the denominator of the age equation. 
Table 3. Dose rate measurements.

\begin{tabular}{|c|c|c|c|c|c|c|}
\hline \multirow[b]{2}{*}{ Sample } & \multirow{2}{*}{$\begin{array}{l}{ }^{238} U \\
(\text { ppm })\end{array}$} & \multirow{2}{*}{$\begin{array}{l}{ }^{233} \mathrm{Th} \\
(\mathrm{ppm})\end{array}$} & \multirow{2}{*}{$\begin{array}{c}K \\
(\%)\end{array}$} & \multicolumn{2}{|c|}{ Beta dose rate $(\mathrm{Gy} / \mathrm{ka})$} & \multirow{2}{*}{$\begin{array}{l}\text { Total dose rate* } \\
\qquad(G y / k a)\end{array}$} \\
\hline & & & & ß-counting & $\begin{array}{l}\text {-counting/ } \\
\text { flame photometry }\end{array}$ & \\
\hline UW1943 & $3.63 \pm 0.23$ & $7.86 \pm 0.92$ & $1.94 \pm 0.12$ & $2.20 \pm 0.20$ & $2.31 \pm 0.11$ & $5.18 \pm 0.27$ \\
\hline Sediment & $2.82 \pm 0.21$ & $8.25 \pm 1.19$ & $0.94 \pm 0.03$ & & & \\
\hline UW1944 & $2.80 \pm 0.19$ & $6.03 \pm 0.92$ & $0.90 \pm 0.03$ & $1.24 \pm 0.11$ & $1.29 \pm 0.05$ & $4.12 \pm 0.22$ \\
\hline Sediment & $2.34 \pm 0.19$ & $8.78 \pm 1.21$ & $0.93 \pm 0.04$ & & & \\
\hline UW1945 & $3.13 \pm 0.22$ & $8.95 \pm 1.26$ & $1.39 \pm 0.05$ & $1.74 \pm 0.16$ & $1.82 \pm 0.06$ & $4.10 \pm 0.19$ \\
\hline Sediment & $2.14 \pm 0.13$ & $1.81 \pm 0.55$ & $0.90 \pm 0.06$ & & & \\
\hline UW1946 & $2.51 \pm 0.18$ & $5.89 \pm 1.00$ & $1.59 \pm 0.14$ & $1.65 \pm 0.16$ & $1.80 \pm 0.12$ & $3.36 \pm 0.16$ \\
\hline Sediment & $2.52 \pm 0.18$ & $5.52 \pm 0.97$ & $0.87 \pm 0.06$ & & & \\
\hline
\end{tabular}

* Dose rate calculated for thermoluminescence. It will be slightly lower for optically stimulated luminescence because of lower alpha efficiency.

Equivalent dose, which is the laboratory estimation of the accumulated radiation dose and is the numerator of the age equation, was determined on fine-grain $(1-8 \mu \mathrm{m})$ polymineral materials. It was measured by thermoluminescence (TL), infrared stimulated luminescence (IRSL), and optically stimulated luminescence (OSL). The TL measurements, in general, were characterized by poor temperature plateaus (Table 4). In only one sample from the Tuinier Farm site did the plateau (the region of constant equivalent dose) extend to $320^{\circ} \mathrm{C}$, symptomatic of relatively low firing conditions. Anomalous fading, which is a loss of signal through time and is characteristic of feldspar minerals, was ubiquitous, and apparent in all samples (Table 4).

Table 4. TL parameters.

\begin{tabular}{c|cccc}
\hline Sample & Plateau $\left({ }^{\circ} \mathrm{C}\right)$ & $I^{\text {st }} / 2^{\text {nd }}$ ratio $^{*}$ & fit & g-value** \\
\hline UW1943 & $250-310$ & 1 & quadratic & $2.93 \pm 2.88$ \\
UW1944 & $280-310$ & 1 & Linear & $6.97 \pm 3.73$ \\
UW1945 & $250-300$ & $0.82 \pm 0.06$ & Linear & $7.95 \pm 1.70$ \\
UW1946 & $250-320$ & $2.12 \pm 0.21$ & Linear & $2.84 \pm 2.77$ \\
\hline
\end{tabular}

*Refers to slope ratio between the first and second glow growth curves. A glow refers to luminescence as a function of temperature; a second glow comes after heating to $450^{\circ} \mathrm{C}$. Growth curves plot luminescence as a function of absorbed dose.

** $\mathrm{g}$-value is the anomalous fading rate expressed as \% per decade, where a decade is a power of 10 .

OSL was measured on five or six aliquots per sample. The scatter among aliquots was not high, only 15 percent over-dispersion for UW1943 and UW1944, and less than 5 percent for the other two samples. The OSL signal was generally strong, at least 10 times the intensity of the IRSL signal (as measured in the ultraviolet). The IRSL signal was not even measurable on UW1943. Weak IRSL relative to OSL is typical for ceramics, and because IRSL mainly stems from feldspars, which commonly fade, this probably means that the OSL signal in these samples does not suffer appreciably from anomalous fading. Equivalent dose values are given in Table 5, along with b-values, which is a measure of the lower efficiency of alpha irradiation in producing luminescence. The equivalent dose values differ among TL, IRSL and OSL, which is not surprising given that the $b$-values, the values of which are fairly typical, also differ. The meaningful comparison is among ages.

Table 5. Equivalence dose values.

\begin{tabular}{c|cccccc}
\hline Sample & \multicolumn{3}{|c}{ Equivalent dose $(G y)$} & \multicolumn{3}{c}{$b$-value $\left(G y \mu m^{2}\right)$} \\
\hline & $T L$ & $I R S L$ & $O S L$ & $T L$ & $I R S L$ & $O S L$ \\
UW1943 & $3.56 \pm 0.20$ & None & $6.18 \pm 0.44$ & $2.50 \pm 0.23$ & & $0.82 \pm 0.04$ \\
UW1944 & $2.06 \pm 0.08$ & $2.59 \pm 0.57$ & $1.59 \pm 0.11$ & $2.94 \pm 0.25$ & $1.11 \pm 0.11$ & $0.80 \pm 0.03$ \\
UW1945 & $2.51 \pm 0.22$ & $2.47 \pm 0.20$ & $1.60 \pm 0.04$ & $1.98 \pm 0.15$ & $1.23 \pm 0.11$ & $0.49 \pm 0.01$ \\
UW1946 & $1.76 \pm 0.10^{*}$ & $2.57 \pm 0.40$ & $1.45 \pm 0.02$ & $1.39 \pm 0.08$ & $1.30 \pm 0.09$ & $0.41 \pm 0.01$ \\
\hline
\end{tabular}


Table 6 gives the ages calculated separately for TL, IRSL, and OSL for each of the Tuinier Farm sherd samples. For samples with evidence of fading of the TL signal, the correction procedure of Huntley and Lamothe (2002) was applied. No fading tests were done for either IRSL or OSL (because of exorbitant amount of machine time required), so no correction can be applied to them. The IRSL signal mainly comes from feldspars, which often fade, so the IRSL ages must be considered a minimum. The weak IRSL, and therefore feldspar signal suggests that the OSL signal probably comes mainly from quartz and does not fade, as mentioned earlier.

Table 6. TL, IRSL, and OSL age calculations for Tuinier Farm sherds.

\begin{tabular}{c|lcl}
\hline Sample & TL age $(\mathrm{ka})$ & IRSL age $(\mathrm{ka})$ & OSL age $(\mathrm{ka})$ \\
\hline UW1943 & $0.69 \pm 0.06$ & & $1.64 \pm 0.14$ \\
UW1944 & $0.50 \pm 0.04$ & $0.89 \pm 0.21$ & $0.59 \pm .05$ \\
UW1945 & $0.92 \pm 0.14 *$ & $0.71 \pm 0.07$ & $0.57 \pm 0.03$ \\
UW1946 & $0.52 \pm 0.04$ & $0.78 \pm 0.13$ & $0.53 \pm 0.03$ \\
\hline \multicolumn{2}{r}{ * Corrected for fading using Huntley-Lamothe (2002) method. Other TL ages reflect either no measured fading or a correction that }
\end{tabular}
was not significantly different from the uncorrected age.

Table 6 shows that the OSL age is younger than or equivalent in value to the TL ages in three of the sherds, but well older than the TL age for UW1943. The younger OSL age for UW1945 is unusual, but a possible reason is the low original firing temperature of the pottery. It is well known, at least in the case of light exposure, that the traps associated with TL and IRSL do not empty as rapidly as they do for OSL. It is possible the original firing of the pottery was not sufficient to deplete the TL and IRSL signals to the same extent as the OSL signal. In other words, the TL and IRSL still contain a residual signal from the raw material. OSL is also known to contain slower bleaching components, so it is possible that a residual is present even with the OSL. Nevertheless, the OSL is assumed to provide the best estimate of age for UW1944 and UW1945 (Table 7). For UW1946, the OSL and TL ages are in agreement, so a weighted average is taken. For UW1943, the OSL age is much greater than the TL age. The OSL age seemed unreasonably old, so the TL was taken as the best estimate.

Table 7. Final ages for Tuinier Farm sherds, based on TL and OSL.

\begin{tabular}{c|cccc}
\hline Sample & Age $(\mathrm{ka})$ & \% error & Calendar age (years AD) & Basis for age \\
\hline UW1943 & $0.69 \pm 0.06$ & 8.3 & $1320 \pm 60$ & TL \\
UW1944 & $0.59 \pm 0.05$ & 8.6 & $1420 \pm 50$ & OSL \\
UW1945 & $0.57 \pm 0.03$ & 5.1 & $1440 \pm 30$ & OSL \\
UW1946 & $0.52 \pm 0.03$ & 4.8 & $1480 \pm 30$ & OSL/TL \\
\hline
\end{tabular}

The ages for the sherd samples from the Tuinier Farm sites are all older than expectations, as they range from A.D. 1260-1510 at 1 standard deviation. Taking out the significantly older UW1943 sherd, the weighted age of UW1944, UW1945, and UW1946 is AD $1460 \pm 20$, about 100 years older at 2 standard deviations than the estimates obtained from ceramic stylistic analysis and the period of overlap from two radiocarbon dates (see Table 1).

The UW1946 sample from the Tuinier Farm site, considering the error term, could be post-A.D. 1500 in age (see Table 7). It is significant that the UW1946 sample is the only one where the OSL and TL ages agree. This lends support to the hypothesis that insufficient heating may be causing the age overestimation for the other samples. These ceramics were part of a larger lot submitted for analysis (Feathers 2010), most of which seemed to have age overestimations. A number of these ceramics were reported as "soft" by the students preparing them for measurement, which suggests low firing. These can be compared to another batch of Caddo ceramics processed from the Lang Pasture site (41AN38). These also had poor plateaus indicative of low heating, but the OSL and TL agreed for most of them and the ages were not known to be overestimates, see Feathers 2008; Perttula 2008). 


\section{Conclusions}

The luminescence dating of four Late Caddo period sherds from the Tuiner Farm site (41HP237) is a recent attempt to better establish the chronological age of Caddo ceramics-and the components they are associated with-on East Texas Caddo sites. Radiocarbon dating and Oxidizable Carbon ratio dating methods have been employed on a wide range of Caddo sites (see Perttula 1997), but not always with satisfactory results, and often with contradictory results when assessed relative to archaeological estimates of when a site is occupied. Luminescence dating of ceramic sherds may be more useful in attempts to build and strengthen regional Caddo chronologies in East Texas. This is simply because the dating result obtained from luminescence dating is specific to the manufacture and use of a ceramic vessel or a umber of ceramic vessels since it measures the time that has elapsed since a ceramic vessel was last heated, and in archaeological terms that time usually corresponds to when that vessel was manufactured or used, and not necessarily to when that vessel was broken and discarded or entered the archaeological record (see Lipo et al. 2005; Feathers 2009).

In the case of the luminescence dates from the Tuinier Farm sherds (excluding UW1943), their weighted age is A.D. $1460 \pm 20$, or the ages range from A.D. 1420-1500 at two standard deviations. This weighted age for the luminescence dates is in complete concordance with one of the calibrated radiocarbon dates from the site, which has a AD 1460 intercept and a AD 1440-1490 age range at 1 sigma (see Table 1). Furthermore, the principal Ripley Engraved motifs identified in the Tuinier Farm fine ware sherds (see Perttula 2009:Table 5), are known to occur in seriated burial lot contexts dating at its broadest from ca. A.D. 1430-1600 (see Perttula 1992:Table A-2), also confirming the accuracy of the luminescence dating findings.

The second radiocarbon date from the Tuinier Farm site, cal AD 1520-1670 at 2 sigma with a AD 1650 intercept, as well as the occurrence of post-A.D. 1550 ceramic types and motifs (including Ripley Engraved, pendant triangle motif; Womack Engraved; Taylor Engraved; and Hodges Engraved, see Perttula 2009:Table 5), would seem to indicate that there is a second and younger Titus phase occupation at the site. No luminescence dates have been obtained on sherds from any of the afore-mentioned post-A.D. 1550 fine ware sherds to provide further confirmation of the age of this component.

We think it is important that Caddo archaeologists continue to explore different methods of dating components and the material culture remains that characterize them. Luminescence dating is a credible chronological dating method that rightly deserves further consideration in the dating of the very abundant ceramic artifacts from Caddo sites in East Texas, as well as in southeast Oklahoma, southwest Arkansas, and northwest Louisiana.

\section{References Cited}

Dykeman, D. D., R. H. Towner, and J. K. Feathers

2002 Correspondence in Tree-Ring Dating and Thermoluminescence Dating: A Protohistoric Navajo Pilot Study. American Antiquity 67(1):145-164. 


\section{References Cited (cont.)}

Feathers, J. K.

1997 The Application of Luminescence Dating in American Archaeology. Journal of Archaeological Method and Theory 4:1-66.

2000 Why Luminescence Dating Deserves Wider Application in American Archaeology. In It's About Time, edited by S. Nash, pp. 168-185. University of Utah Press, Salt Lake City.

2003 Use of Luminescence Dating in Archaeology. Measurement Science and Technology 14:1493-1509.

2008 Luminescence Dating of Ceramics from an Archaeological Site in East Texas. Luminescence Dating Laboratory, University of Washington, Seattle.

2009 Problems of ceramic chronology in the Southeast: Does shell-tempered pottery appear earlier than we think? American Antiquity 74:113-142.

2010 Luminescence Analysis of Ceramics from Four Caddoan Sites in East Texas. Luminescence Dating Laboratory, University of Washington, Seattle.

Huntley, D. J. and M. Lamothe

2002 Ubiquity of anomalous fading in K-feldspars, and measurement and correction for it in optical dating. Canadian Journal of Earth Sciences 38:1093-1106.

Lipo, C. P., J. K. Feathers, and R. C. Dunnell

2005 Temporal Data Requirements, Luminescence Dates, and the Resolution of Chronological Structure of Late Prehistoric Deposits in the Central Mississippi Valley. American Antiquity 70(3):527-544.

Perttula, T. K.

1992 "The Caddo Nation": Archaeological \& Ethnohistoric Perspectives. University of Texas Press, Austin.

1997 A Compendium of Radiocarbon and Oxidizable Carbon Ratio Dates from Archaeological Sites in East Texas, with a Discussion of the Age and Dating of Select Components and Phases. Radiocarbon 39(3):305-341.

2008 The Ceramic Artifacts from the Lang Pasture Site (41AN38) and the Place of the Site within an Upper Neches River Basin Caddo Ceramic Tradition. MS on file with the author and Coastal Environments, Inc., Austin.

Perttula, T. K., with contributions by E. Dowd, L. Green, G. Morgan, B. Nelson, L. Schniebs, B. Schriever, J. Todd, and M. Walters

2009 The Archaeology of the $16^{\text {th }}$ and $17^{\text {th }}$ Century Caddo in the Post Oak Savannah of Northeast Texas: The Tuinier Farm (41HP237), R. A. Watkins (41HP238), and Anglin (41HP240) Sites in the Stouts Creek Basin, Hopkins County, Texas. Journal of Northeast Texas Archaeology 30:1-132.

Perttula, T. K. (editor)

2005 Archeological Investigations at the Pilgrim's Pride Site (41CP304), a Titus Phase Community in the Big Cypress Creek Basin, Camp County, Texas. 2 Vols. Report of Investigations No. 30. Archeological \& Environmental Consultants, LLC, Austin.

Reimer, P. J., M. G. L. Baillie, E. Bard, A. Bayliss, J. W. Beck, C. J. H. Bartrand, P. G. Blackwell, C. E. Buck, G. S. Burr, K. B. Cutler, P. E. Damon, R. L. Edwards, R. G. Fairbanks, M. Friedrich, T. P. Guilderson, A. G. Hogg, K. A. Hughen, B. Kromer, G. McCormac, S. Manning, C. B. Ramsey, R. W. Reimer, S. Remmele, J. R. Southon, M. Stuiver, S. Talamo, F. W. Taylor, J. van der Plicht, and C. E. Weyhenmeyer

2004 IntCal04 Terrestrial Radiocarbon Age Calibration, 0-26 Cal Kyr BP. Radiocarbon 46(3):1029-1058. 